\title{
OPTIMASI PENCARIAN RUTE TERPENDEK DISTRIBUSI BARANG MENGGUNAKAN METODE SIMULATED ANNEALING (STUDI KASUS: PD BUMI JAYA INDAH KOTA PONTIANAK)
}

\author{
Edo Ridha Permana ${ }^{1}$, Dwi Marisa Midyanti ${ }^{2}$, Rahmi Hidayati ${ }^{3}$ \\ ${ }^{123}$ Jurusan Rekayasa Sistem Komputer, Fakultas MIPA Universitas Tanjungpura \\ Jalan Prof. Dr. H. Hadari Nawawi Pontianak \\ Telp./Fax : (0561) 577963 \\ e-mail: 1edoridha96@gmail.com, 2dwi.marisa@ siskom.untan.ac.id, \\ 3rahmihidayati@siskom.untan.ac.id.
}

\begin{abstract}
Abstrak
PD Bumi Jaya Indah adalah sebuah perusahaan yang bergerak di bidang jasa dan berperan sebagai distributor barang brand $\mathrm{ABC}$ di kota Pontianak. Permasalahan dalam pengantaran barang yang dilakukan PD Bumi Jaya Indah yaitu rute yang ditempuh tidak optimal akan berdampak pada jarak, biaya dan waktu pengantaran sehingga diperlukan sebuah metode optimasi yang dapat memaksimalkan solusi agar didapatkan hasil dan proses yang optimal. Metode Simulated Annealing adalah satu diantara algoritma optimasi yang dapat menjadi solusi dari permasalahan rute terpendek. Metode Simulated Annealing akan menghitung setiap kemungkinan atau kombinasi rute yang akan dilewati, kemudian akan mengambil nilai terbaik dari seluruh kombinasi rute berdasarkan titik lokasi yang dipilih. Berdasarkan hasil pencarian jarak dan rute terpendek yang dilakukan pada 6 buah titik lokasi yaitu PD Bumi Jaya Indah, Ligo Mitra, Mitra Anda Hasanudin, Ramayana, Anggrek dan Garuda Mitra mendapatkan hasil jarak terpendek yaitu dengan jarak 22,75 Km, biaya sebesar Rp 11287,50 dan waktu 34,125 menit dengan melewati rute (PD Bumi Jaya indah - Ligo Mitra - Ramayana - Anggrek - Garuda Mitra - Mitra Anda Hasanudin - PD Bumi Jaya Indah).
\end{abstract}

Keywords: Jarak Terpendek, Optimasi, Rute, Simulated Annealing.

\section{PENDAHULUAN}

PD Bumi Jaya Indah adalah sebuah perusahaan yang bergerak di bidang jasa. PD Bumi Jaya Indah berperan sebagai distributor yang mendistribusikan barang brand $\mathrm{ABC}$ seperti Kecap, Sambal, Saus Tomat, Sirup dan lain sebagainya. Proses pengantaran barang dilakukan secara berkala tergantung dari kebutuhan masing-masing supermarket, minimarket, grosir, warung, rumah makan atau restoran yang bekerja sama dengan PD Bumi Jaya Indah. PD Bumi Jaya Indah memiliki relasi kerja sama dengan berbagai tempat usaha yang berada di kota Pontianak. Permasalahan yang ditemukan dalam pengantaran barang adalah rute yang ditempuh masih belum optimal. Permasalahan ini akan berdampak pada jarak, waktu pengantaran dan biaya yang dikeluarkan PD Bumi Jaya Indah menjadi tidak efisien. Permasalahan pencarian rute terpendek dapat diselesaikan dengan algoritma optimasi. Metode yang dapat menyelesaikan permasalahan pencarian rute terpendek satu diantaranya adalah Simulated Annealing.

Simulated Annealing adalah sebuah metode berdasarkan terbentuknya pemrosesan logam. Annealing (memanaskan kemudian mendinginkan) dalam proses logam adalah suatu proses bagaimana membuat logam bentuk cair berangsur-angsur menjadi bentuk yang lebih padat seiring dengan penurunan temperatur. Travelling Salesman Problem adalah satu diantara permasalahan yang mana perubahan keadaan dari suatu kondisi ke kondisi lainnya dimana membutuhkan suatu ruang yang sangat luas, contohnya seperti perubahan gerakan dengan menggunakan suatu permutasi yang dapat diselesaikan dengan metode Simulated Annealing[1].

Simulated Annealing memiliki kelebihan yaitu dapat mencari nilai terbaik dengan membandingkan seluruh data dan kemampuan 
untuk menghindari jebakan optimal lokal. Simulated Annealing merupakan suatu algoritma pencarian acak, yang tidak hanya dapat menerima nilai obyektif yang selalu turun, juga terkadang dapat menerima nilai obyektif yang naik [2]. Simulated Annealing adalah algoritma optimasi yang mempunyai sifat generik. Dengan berbasis mekanik statistik dan probabilitas, algoritma ini mempunyai kelebihan dalam pencarian pendekatan suatu permasalahan dengan solusi optimum global dan melalui proses annealing (pendinginan). Pada umumnya, suatu masalah yang membutuhkan algoritma Simulated Annealing adalah optimasi kombinatorial, seperti halnya tidak memungkinkan solusi optimum untuk sebuah permasalahan dalam ruang pencarian solusi yang begitu kompleks [3].

Menurut [4] dalam penelitian yang dilakukan menggunakan metode Simulated Annealing untuk menyelesaikan kasus Travelling Salesman Problem (TSP). Pada proses penelitian hal yang harus dilakukan yaitu menentukan rute terpendek, biaya dan waktu tempuh menggunakan metode Simulated Annealing. Hasil dari proses tersebut akan menghasilkan rute dengan jarak terpendek, waktu dan biaya tempuh yang efisien.

Penelitian lain tentang Simulated Annealing dilakukan [5] dari Institut Teknologi Sepuluh November. Pada penelitian ini, penentuan rute distribusi produk air minum dalam kemasan dengan menggunakan algoritma Simulated Annealing dengan bantuan visualisasi dari Google Maps. Hasil dari penelitian ini yaitu metode Simulated Annealing dapat menghasilkan rute kendaraan dengan jarak tempuh terpendek, informasi penggunaan kendaraan dan jumlah biaya yang dibutuhkan dalam pendistribusian barang. Rute terpendek ditampilkan dalam bentuk visual dengan teknologi Google Maps.

Dalam penelitian yang dilakukan [6], penentuan jalur terpendek oleh pelayanan agen travel adalah sebuah permasalahan yang harus diperhatikan. Penelitian menggunakan algoritma Branch And Bound diharapkan dapat mencari rute terpendek yang akan berdampak biaya dan waktu yang dikeluarkan oleh travel agen menjadi lebih efisien. Hasil penelitian yang didapatkan yaitu pencarian rute terpendek dapat memberikan keuntungan pada agen travel dalam pengantaran penumpang dan berdampak pada penghematan waktu dan biaya transportasi.

Berdasarkan penelitian terkait, akan dibangun sebuah aplikasi untuk mencari rute terpendek pada perusahaan PD Bumi Jaya Indah menggunakan metode Simulated Annealing yang diharapkan dapat menjadi solusi untuk masalah optimasi, terutama untuk menemukan rute terpendek dalam suatu pendistribusian barang.

\section{LANDASAN TEORI}

\subsection{Algoritma Optimasi}

Algoritma optimasi adalah suatu jenis algoritma yang berfungsi untuk memaksimalkan solusi dari suatu permasalahan agar didapatkan sebuah proses dan hasil yang optimal. Operasi algoritma optimasi terbagi menjadi dua metode, yaitu algoritma deterministik dan algoritma probabilistik. Perbedaan mendasar dari kedua jenis algoritma optimasi adalah setiap langkah eksekusi dalam proses algoritma optimasi deterministik hanya terdapat satu jalan untuk diproses, namun jika tidak ada jalan lain, maka algoritma akan dianggap selesai. Dengan demikian algoritma akan selalu menghasilkan solusi tetap dari suatu input yang diberikan. Algoritma optimasi digunakan untuk suatu permasalahan dengan skala yang tidak terlalu besar. Pada algoritma optimasi probabilistik, algoritma probabilistik digunakan untuk menyelesaikan permasalahan dengan ruang solusi yang lebih besar, bahkan tidak terbatas. Algoritma optimasi probabilistik akan menemukan solusi yang bagus tanpa melewati batasan waktu yang telah ditetapkan. Solusi bagus optimasi probabilistik belum tentu paling optimal, namun sudah dapat diterima user. Contoh dari algoritma optimasi yaitu Tabu Search, Dynamic Programming, Monte Carlo, Simulated Annealing dan lain sebagainya[7].

\subsection{Simulated Annealing}

Simulated Annealing merupakan metode yang dikembangkan dari analogi pada proses pendinginan logam cair hingga akhirnya membentuk kristal yaitu annealing. Annealing adalah sebuah teknik pada bidang metalurgi yang menggunakan proses penjadwalan pendinginan logam untuk menghasilkan efisiensi penggunaan energi yang optimal. Prinsip kerja 
Simulated Annealing yaitu pada temperatur yang tinggi, molekul-molekul cairan mempunyai tingkat energi yang tinggi sehingga cenderung mudah bergerak terhadap molekul lainnya. Jika temperatur diturunkan, molekul-molekul tersebut akan mengatur untuk mencari susunan atau konfigurasi dengan tingkat energi yang lebih rendah. Dengan menurunkan temperatur secara perlahan, molekul-molekul tersebut diberikan kesempatan untuk mengatur diri sendiri sehingga diperoleh sebuah keadaanstabil dengan tingkat energi minimum. Penurunan temperatur secara perlahan disebut proses annealing yang digunakan untuk menyelesaikan masalah Travelling Salesman Problem (TSP) sehingga diperoleh solusi optimal[1].

Simulated Annealing adalah sebuah bentuk varian dari teknik Heuristic Search Hill Climbing, dimana variasi tersebut adalah kebalikan dari Steepest Hill Climbing. Variasi rute yang dipilih untuk di observasi merupakan rute yang terendah atau memiliki bobot nilai terkecil. Heuristic Search adalah sebuah cara untuk meningkatkan efisiensi dari sebuah pencarian[8].

Hal-hal yang harus diperhatikan dalam proses Simulated Annealing yaitu sebagai berikut [9]:

1. Inisialisasi rute awal yang dipilih secara random. Memilih rute awal dengan cara random sebagai posisi awal iterasi dalam proses Simulated Annealing.

2. Parameter awal memiliki nilai yang cukup besar agar dapat terhindar dari bad local optimal.

3. Mekanisme pertukaran. Proses pertukaran dilakukan dengan menentukan kota yang dibutuhkan sebagai pertukaran solusi yang dianggap sebagai iterasi.

4. Fungsi objektif permasalahan. Proses evaluasi dari setiap fungsi biaya yang berubah karena proses iterasi dari mekanisme pertukaran.

5. Annealing schedule. Fungsi annealing schedule yang digunakan adalah :

$$
T_{i+1}=\alpha \times T_{i}
$$

$\alpha$ (alpha) adalah sebuah konstanta untuk menurunkan parameter kontrol dengan $\alpha<1$. Pengalaman menunjukan bahwa $\alpha$ yang digunakan sebaiknya adalah antara 0,8 sampai 0,99. Hasil yang baik biasanya diperoleh ketika $\alpha$ mendekati 0.99. Tetapi, semakin besar $\alpha$ maka akan semakin lama pula proses penurunan temperatur untuk mencapai kriteria berhenti.

6. Kriteria penghentian proses Simulated Annealing. Beberapa metode yang biasa digunakan sebagai mengontrol penghentian algoritma yaitu dilihat dari:

1) Maksimum jumlah iterasi.

2) Nilai minimum parameter kontrol.

3) Nilai minimum fungsi objektif.

4) Nilai minimum dari tingkat penerimaan.

Struktur algoritma Simulated Annealing pada Travelling Salesman Problem adalah sebagai berikut [7] :

1. Evaluasi rute awal. Jika rute awal merupakan sebuah tujuan, maka pencarian keluar dan selesai. Jika bukan, maka lanjutkan dengan menetapkan rute awal sebagai rute sekarang.

2. Inisialisasi BEST-SO-FAR dengan rute sekarang.

3. Inisialisasi sesuai dengan annealing schedule.

4. Ulangi hingga solusi ditemukan atau sudah tidak ada lagi aturan yang bisa diaplikasikan ke rute sekarang.

a. Pilih sebuah aturan belum pernah digunakan untuk menghasilkan rute baru.

b. Evaluasi rute yang baru dengan menghitung menggunakan:

$$
\Delta E=Z_{c}-Z_{n}
$$

1) Jika rute baru merupakan sebuah tujuan, maka pencarian keluar dan berhasil.

2) Jika rute baru bukan merupakan tujuan tetapi mempunyai nilai yang lebih baik daripada rute sekarang $\left(Z_{n} \leq Z_{c}\right)$ maka tetapkan rute baru sebagai rute sekarang. Demikian juga tetapkan BEST-SO-FAR ke rute yang baru.

3) Jika nilai rute baru tidak lebih baik dibandingkan nilai rute sekarang $\left(Z_{n}>\right.$ $Z_{c}$ ) maka rute baru ditetapkan sebagai rute sekarang dengan probabilitas:

$$
p=e^{\frac{Z_{c}-Z_{n}}{T_{i}}}
$$

$Z_{c}=$ Nilai rute sekarang. 
$Z_{n}=$ Nilai rute baru.

$T_{i}=$ Sebuah parameter yang cenderung untuk menerima rute baru.

Langkah ini dikerjakan dengan membangkitkan sebuah bilangan random pada interval $[0,1]$. Jika $\mathrm{r}<\mathrm{p}$, maka rute baru menjadi rute sekarang. Jika tidak, maka tidak akan dikerjakan apapun.

\section{c. Perbaiki $\mathrm{T}$ berdasarkan annealing} schedule.

5. BEST-SO-FAR merupakan solusi minimum global yang diharapkan.

Berikut ini adalah langkah-langkah yang dilakukan pada Travelling Salesman Problem:

1) Tentukan rute awal dengan memilih rute awal yang dilalui salesman secara random dan hitung total biaya perjalanan $\left(Z_{c}\right)$.

2) Tentukan $\mathrm{T}$ awal yaitu $T_{i}=\alpha \times Z_{c}$ dengan $\mathrm{i}=1$, $\alpha=0,99$ dan $Z_{c}$ biaya, jarak tempuh dan waktu rute awal yang dilalui salesman secara random atau acak.

3) 3) Jalankan iterasi dengan menukarkan posisi kota dari rute yang dilalui salesman secara random tadi dengan cara membangkitkan bilangan random pada range $[0,1]$. Evaluasi rute baru dengan cara sebagai berikut:

a) Jika rute baru merupakan sebuah tujuan, maka iterasi dilanjutkan hingga maksimum jumlah iterasi yang dilakukan.

b) Jika rute baru bukan merupakan sebuah tujuan, namun mempunyai nilai yang lebih baik dari rute sekarang $\left(Z_{n} \leq Z_{c}\right)$ maka rute baru dapat di tetapkan sebagai rute sekarang.

c) Jika nilai rute baru tadi tidak lebih baik dibandingkan nilai rute sekarang $\left(Z_{n}>\right.$ $Z_{c}$ ), maka tetapkan rute baru sebagai rute sekarang dengan probabilitas seperti pada persamaan (3). Langkah ini dapat dikerjakan dengan membangkitkan sebuah bilangan random $r$ pada range [0,1]. Jika kondisi nilai $r \leq p$, maka rute baru boleh menjadi rute sekarang. Jika kondisi nilai $r>p$, maka rute baru tidak boleh menjadi rute sekarang.

4) Perbaiki nilai dari $T$ sesuai dengan annealing schedule seperti pada persamaan (1).

5) Lakukan kembali langkah 3 dan 4 untuk selanjutnya menentukan rute yang akan dihitung. Terus lakukan iterasi sampai kriteria terpenuhi.

\subsection{Travelling Salesman Problem}

Travelling Salesman Problem (TSP) adalah sebuah persoalan optimasi yang digunakan untuk mencari perjalanan terpendek bagi salesman yang ingin berkunjung lebih dari 1 tempat. TSP dikenal sebagai suartu masalah optimasi yang menarik perhatian para ahli dari bidang matematika khususnya ilmuwan pada bidang komputer karena TSP mudah didefinisikan namun sulit untuk diselesaikan.

\subsection{Perhitungan Waktu Tempuh}

Perhitungan waktu tempuh dilakukan dengan cara membagi jarak tempuh kendaraan yang digunakan dengan rata-rata kecepatan kendaraan dikali 60 menit. Dari hasil wawancara yang dilakukan dengan kurir/supir PD Bumi Jaya Indah, diperoleh kecepatan rata-rata kendaraan sebesar $40 \mathrm{~km} / \mathrm{jam}$ (Sesuai dengan undang-undang nomor 22 tahun 209 tentang lalu lintas angkutan umum dan batas kecepatan dalam kota Pontianak). Berikut penghitungan waktu tempuh kendaraan :

Waktu tempuh $=\frac{\operatorname{Jarak}(\mathrm{Km})}{\text { kecepatan rata-rata }} \times 60$ menit

\subsection{Perhitungan Biaya Tempuh}

Perhitungan biaya pengantaran dapat dilakukan dengan membagi jarak tempuh dengan rata-rata konsumsi bahan bakar kemudian dikali dengan harga bajan bakar perliter. Pada proses pengantaran barang, PD Bumi Jaya Indah menggunakan mobil pickup jenis Daihatsu Grand Max yang menggunakan bahan bakar bensin atau premium, dengan jumlah rata-rata konsumsi bahan bakar yaitu 13 $\mathrm{km} / 1$ liter, dan harga 1 liter bensin adalah $\mathrm{Rp}$ 6.450

\subsection{PD Bumi Jaya Indah}

PD Bumi Jaya Indah adalah sebuah perusahaan di kota Pontianak yang bergerak di bidang jasa. PD Bumi Jaya Indah berperan sebagai distributor yang mendistribusikan barang brand $\mathrm{ABC}$ seperti kecap, sambal, saus tomat, dan lain sebagainya. PD Bumi Jaya Indah memiliki pegawai yang berjumlah 30 orang. PD 
Bumi Jaya Indah juga memiliki 2 buah mobil pickup yang digunakan sebagai pengantaran barang.

\section{METODE PENELITIAN}

Penelitian pencarian rute terpendek distribusi barang menggunakan metode Simulated Annealing dilakukan dengan berbagai tahapan, dimulai dengan studi literatur, metode pengumpulan data, analisis kebutuhan, perancangan sistem, implementasi dan pengujian. Penelitian yang dilakukan melalui studi literatur mengenai metode Simulated Annealing pada berbagai permasalahan terutama mengenai pencarian rute terpendek dan Travelling Salesman Problem. Metode pengumpulan data dilakukan dengan cara observasi dan wawancara dengan pihak PD Bumi Jaya Indah selaku distributor barang brand ABC. Dari pengumpulan data ini dapatkan hasil berupa daftar supermarket dan minimarket yang bekerja sama dengan PD Bumi Jaya Indah. Analisis kebutuhan diperlukan untuk mendapatkan informasi yang berisi spesifikasi perangkat keras dan perangkat lunak yang digunakan untuk membangun sistem aplikasi. Selanjutnya perancangan dilakukan dengan menyesuaikan kebutuhan perangkat dan data yang diperoleh. Kemudian implementasi dilakukan dengan membuat antarmuka pengguna (user) dan basis data (databases). Antarmuka pengguna dibuat dengan menggunakan bahasa pemrograman PHP.

Tahap pengujian dilakukan sebagai tolak ukur apakah aplikasi sudah befungsi dengan baik dan sesuai dengan tujuan yang diharapkan. Pengujian yang dilakukan yaitu dengan membandingkan rute dan jarak terpendek yang didapatkan oleh aplikasi menggunakan metode Simulated Annealing dengan rute dan jarak terpendek yang dilalui oleh perusahaan PD Bumi Jaya Indah.

\section{PERANCANGAN}

\subsection{Data Flow Diagram (DFD)}

Terdapat 2 entitas yaitu admin dan user. Pada sistem ini admin dapat memasukkan data admin, data lokasi, dan data distribusi. Selanjutnya keluaran dari sistem berupa info dari data yang telah dimasukkan seperti info admin, info lokasi, info distribusi dan info rute terbaik. Sedangkan user dapat memasukkan data lokasi yang dipilih untuk distribusi. Kemudian user dapat melihat hasil berupa info dari data rute terbaik. DFD Level 0 dapat dilihat pada Gambar 1.

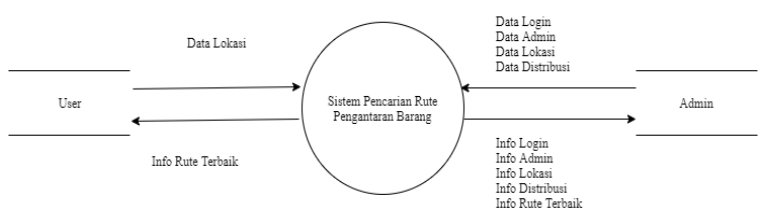

Gambar 1. DFD Level 0

Pada DFD level 1, terdapat beberapa proses, yaitu :

1. Login : Jika Admin berhasil login, maka admin dapat memproses data lainnya. Jika admin gagal melakukan login, maka akan diberikan info kesalahan pada username atau password.

2. Admin : Admin dapat meng-input data lokasi, dan data distribusi.

3. User menginput titik-titik lokasi pengantaran kemudian oleh sistem akan diproses dan menghasilkan lokasi beserta rute terpendek untuk pendistribusian barang.

DFD level 1 dapat dilihat pada Gambar 2.

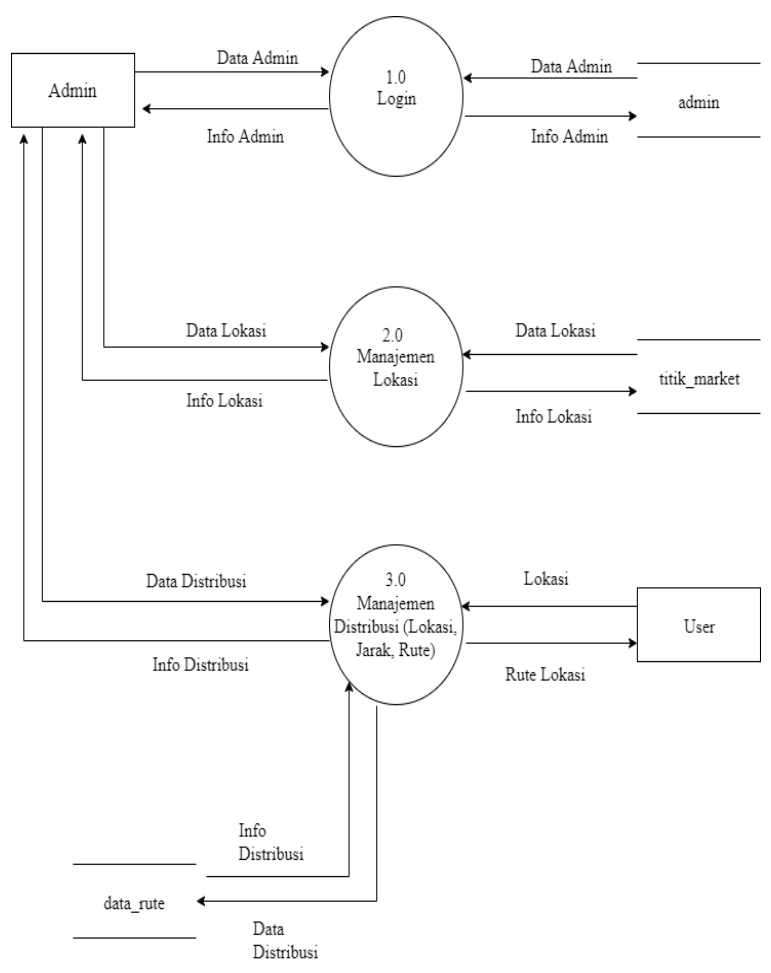

Gambar 2. DFD Level 1 


\subsection{Flowchart}

Flowchart Travelling Salesman Problem menggunakan Simulated Annealing dapat dilihat pada Gambar 3.

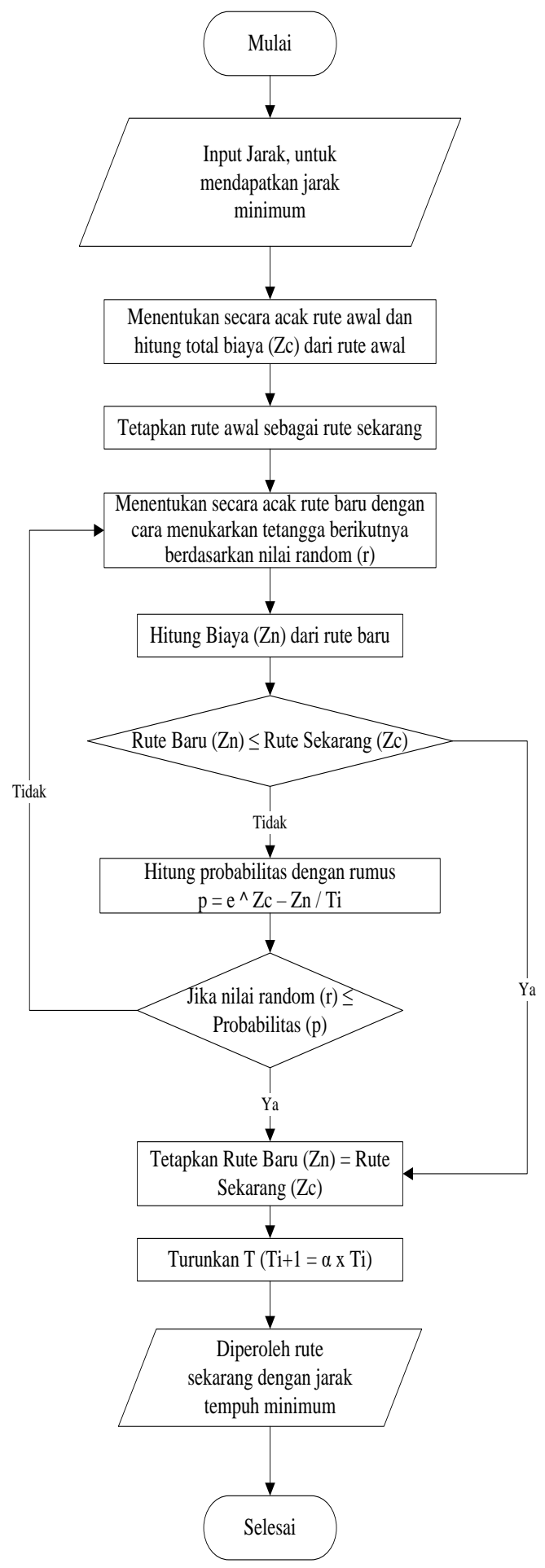

Gambar 3. Flowchart

\section{IMPLEMENTASI, PENGUJIAN DAN PEMBAHASAN}

\subsection{Implementasi Sistem}

Berikut merupakan tampilan dari masingmasing antarmuka aplikasi pencarian rute terpendek pengantaran barang menggunakan Simulated Annealing pada perusahaan PD Bumi Jaya Indah.

\subsubsection{Halaman Login}

Tampilan Halaman Login dapat dilihat pada Gambar 4.

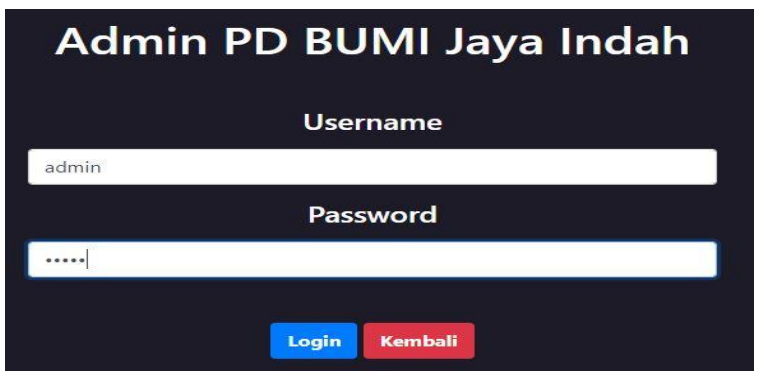

Gambar 4. Tampilan Halaman Login

\subsubsection{Halaman Dashborad Admin}

Tampilan halaman awal setelah admin selesai login. Terdapat menu di bagian atas yang terdiri dari lokasi, distribusi, admin, dan data perhitungan. Selain itu, terdapat beberapa indikator suhu awal, suhu akhir, nilai alpha dan juga jumlah iterasi. Tampilan Dashboard admin dapat dilihat pada Gambar 5.

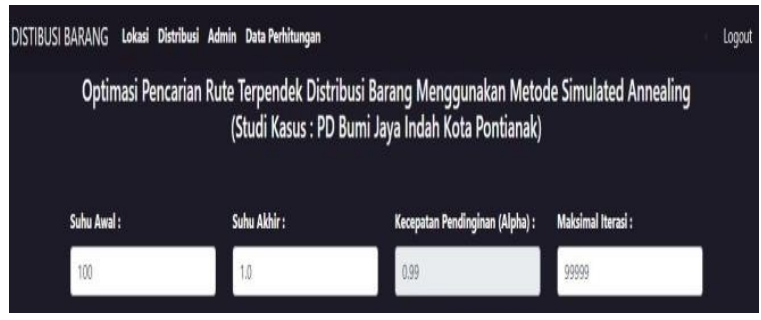

Gambar 5. Antarmuka Dashboard Admin

\subsubsection{Halaman Daftar Lokasi}

Halaman Daftar Lokasi berisi daftar lokasi supermarket dan minimarket yang terdaftar sebagai tempat pendistribusian barang-barang brand $\mathrm{ABC}$ dari PD Bumi Jaya Indah. Terdapat tombol edit dan hapus yang berada di samping sebelah kanan nama lokasi. Tampilan halaman daftar lokasi dapat dilihat pada Gambar 6. 


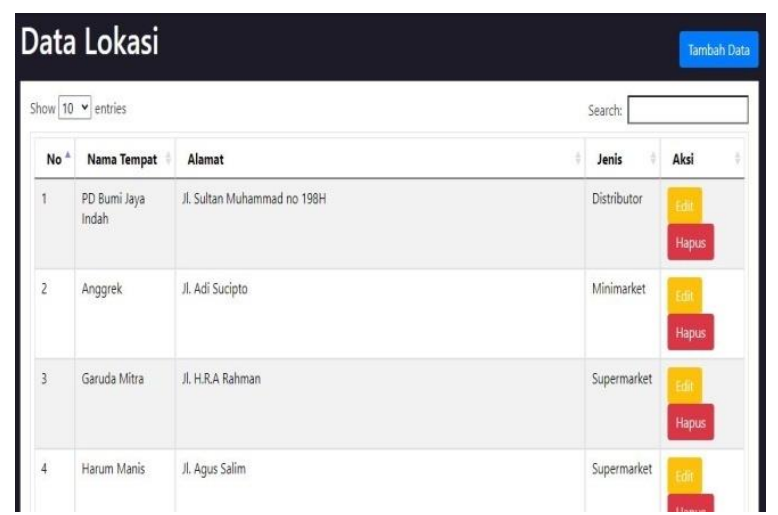

Gambar 6. Antarmuka Daftar Lokasi

\subsubsection{Halaman Daftar Distribusi}

Halaman Daftar Distribusi berisi daftar nama lokasi sebagai titik permulaan dan titik tujuan dari pendistribusian barang. Pada halaman ini terdapat daftar berupa titik awal, titik tujuan, jarak, biaya, waktu dan rute. Tampilan halaman daftar distribusi pada website admin dapat dilihat pada Gambar 7.

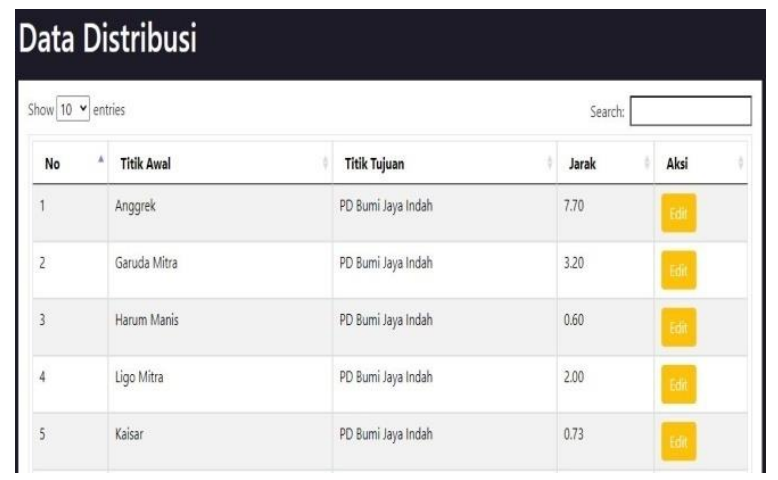

Gambar 7. Tampilan Halaman Daftar Distibusi

\subsubsection{Tampilan Halaman User}

Halaman user adalah halaman yang menampilkan 30 titik atau nama tempat yang terdiri dari, supermarket dan minimarket yang berada di kota Pontianak. Pada tampilan halaman ini terdapat marker yang berfungsi sebagai penanda lokasi dari supermarket. User hanya dapat memasukkan atau menginput lokasi supermarket atau minimarket yang akan dituju. User tidak didapat mengubah informasi lokasi dan distribusi. Tampilan Halaman user Gambar 8.

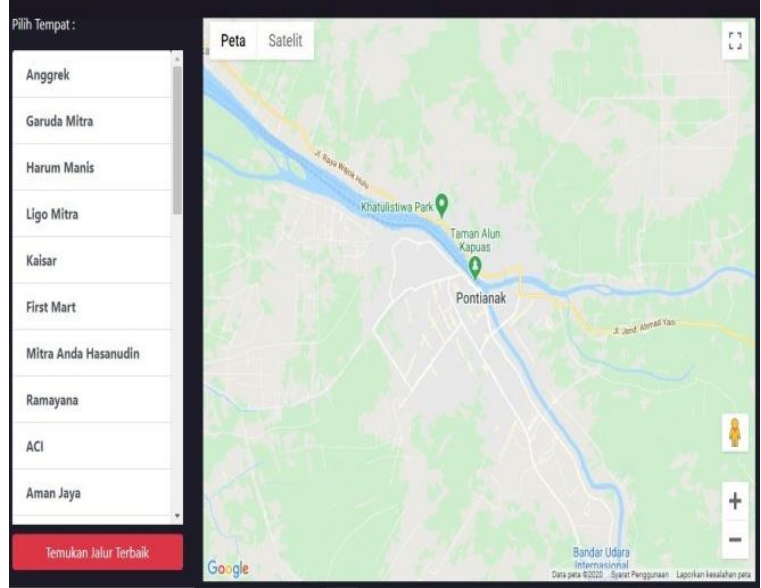

Gambar 8. Tampilan Halaman User

\subsection{Pengujian.}

Perusahaan PD Bumi Jaya Indah memiliki kerjasama dengan berbagai supermarket dan minimarket di kota Pontianak. Daftar pendistribusian barang ke supermarket dan minimarket dapat dilihat pada Tabel 1 .

Tabel 1. Distribusi Barang

\begin{tabular}{|c|l|}
\hline No & Nama Supermarket/Minimarket \\
\hline 1 & PD Bumi Jaya Indah \\
\hline 2 & Anggrek \\
\hline 3 & Garuda Mitra \\
\hline 4 & Harum Manis \\
\hline 5 & Ligo Mitra \\
\hline 6 & Kaisar \\
\hline 7 & First Mart \\
\hline 8 & Mitra Anda Hasanudin \\
\hline 9 & Ramayana \\
\hline 10 & ACI \\
\hline 11 & Aman Jaya \\
\hline 12 & Asoka Baru \\
\hline 13 & Catelya Mart \\
\hline 14 & Mitra Maju \\
\hline 15 & Mitra Makmur \\
\hline 16 & Gita Mart \\
\hline 17 & Maju MM \\
\hline 18 & Lucky MM \\
\hline
\end{tabular}


Coding : Jurnal Komputer dan Aplikasi

Volume 8, No. 03 (2020), hal 9-18

ISSN: $2338-493 \mathrm{X}$

Tabel 1. Distribusi Barang (Lanjutan)

\begin{tabular}{|c|c|}
\hline No & Nama Supermarket/Minimarket \\
\hline 19 & Prima Jaya \\
\hline 20 & Prime Mart \\
\hline 21 & Cempaka Mas \\
\hline 22 & Atie Mart \\
\hline 23 & Citra Abadi \\
\hline 24 & Happy Mart Pancasila \\
\hline 25 & Mama MM \\
\hline 26 & Mitra Jeruju \\
\hline 27 & Ponti Suri Mart 3 \\
\hline 28 & Mini Super \\
\hline 29 & Royal \\
\hline 30 & Citra Kita \\
\hline
\end{tabular}

Pada pengujian ini dilakukan dengan pemilihan lokasi yang akan di cari rute terpendeknya. Lokasi rute awal ditentukan secara random. Adapun rute awal yang ditetapkan adalah 0-1-2-3-4-5-0 dengan 0 sebagai titik awal dan titik akhir pengantaran.

Berikut daftar lokasi berdasarkan rute awal:

0. PD Bumi Jaya Indah

1. Ligo Mitra

2. Mitra Anda Hasanudin

3. Ramayana

4. Anggrek

5. Garuda Mitra

\section{Langkah :}

1) Menentukan rute awal dengan menentukan rute awal secara random. Kemudian hitung jarak, biaya dan waktu dari setiap titik.

$$
\begin{aligned}
\text { Jarak }(d)= & 2,3+3,2+3,6+5,8+9,6+3,2 \\
= & 27,7 \\
\text { Biaya }(c)= & 1141,15+1587,69+1786,15+ \\
& 2877,69+4763,07+1587,69 \\
= & 13743,46 \\
\text { Waktu }(d)= & 3,4+4,8+5,4+8,7+14,4+ \\
& 4,8 \\
= & 41,5
\end{aligned}
$$

2) Tentukan $\mathrm{T}$ awal yaitu $T_{i}=\alpha \times Z_{c}$ dengan $\mathrm{i}$ $=1, \alpha=0,99$ dan $Z_{c}$ adalah jarak, biaya, dan waktu tempuh rute yang dilalui secara random.
3) Kemudian lakukan iterasi 1.

Proses Iterasi 1 hampir sama dengan proses pada iterasi 0 .

Iterasi 1 :

Langkah yang dilakukan yaitu membangkitkan bilangan random untuk menentukan jalan 1, jalan 2 , jalan 3 dan jalan 4 pada range $[0,1]$ :

$0,00-0,24$ rute perjalanan awal menuju jalan 1

$0,25-0,49$ rute perjalanan awal menuju jalan 2

$0,50-0,74$ rute perjalanan awal menuju jalan 3

$0,75-0,99$ rute perjalanan awal menuju jalan 4

Bilangan random yang dibangkitkan adalah $\mathrm{r}=$ 0,1583 , maka terletak pada jalan 1 . Selanjutnya membangkitkan lagi suatu bilangan random untuk menentukan jalan 2, jalan 4 , dan jalan 5 pada range $[0,1]$

$0,00-0,32$ rute perjalanan akhir menuju jalan 2 $0,33-0,65$ rute perjalanan akhir menuju jalan 4 $0,66-0,98$ rute perjalanan akhir menuju jalan 5

Bilangan random yang dibangkitkan adalah $\mathrm{r}=$ 0,1583 , maka terletak pada jalan 2. Langkah berikutnya menukar antara jalan 1 dan jalan 2 sehingga diperoleh rute :

$$
\begin{aligned}
& 0-2-1-3-4-5-0 \\
\text { Jarak }(\mathrm{d})= & 4,6+2,8+3,8+5,8+9,6+9,2 \\
= & 27,8 \\
\text { Biaya }(\mathrm{c})= & 2282,30+1587,69+893,07+ \\
& 2877,69+2763,07+1587,69 \\
= & 13793,08 \\
\text { Waktu }(\mathrm{d})= & 6,9+4,2+2,7+8,7+14,4+4,8 \\
= & 41,7
\end{aligned}
$$

Karena $Z_{n}>Z_{c}$, maka tetapkan rute baru sebagai rute sekarang dengan probabilitas persamaan (3).

Hasil probabilitas yang didapatkan dari perhitungan pada persamaan (3) adalah 0,9970.

Karena $\mathrm{r}<\mathrm{p}$, maka rute baru dapat ditetapkan sebagai rute sekarang. Selanjutnya, lakukan annealing schedule untuk mencari $T_{2}$ dan hitung jarak, biaya, dan waktu. Proses iterasi dilakukan sampai suhu akhir bernilai 1.0.

Perbandingan pengujian total jarak menggunakan Simulated Annealing dan rute perusahaan PD Bumi Jaya Indah menggunakan 
6 buah lokasi distribusi barang yang berbeda dapat dilihat pada Tabel 2 .

Tabel 2. Perbandingan Jarak Perusahaan dan Simulated Annealing

\begin{tabular}{|c|c|c|}
\hline No & Jarak Perusahaan & Jarak SA \\
\hline 1 & 23,35 & 22,75 \\
\hline 2 & 23,61 & 21,31 \\
\hline 3 & 10.45 & 8,31 \\
\hline 4 & 17,33 & 15,88 \\
\hline 5 & 22,38 & 19,9 \\
\hline 6 & 15,46 & 10,87 \\
\hline 7 & 26,25 & 24,91 \\
\hline 8 & 25,39 & 25.39 \\
\hline 9 & 23,2 & 22,52 \\
\hline 10 & 20,36 & 19,54 \\
\hline 11 & 26,63 & 25,96 \\
\hline 12 & 21,12 & 20,74 \\
\hline 13 & 31,16 & 29,52 \\
\hline 14 & 28,75 & 28,13 \\
\hline 15 & 20,43 & 20,16 \\
\hline 16 & 23,71 & 23,45 \\
\hline 17 & 23,36 & 21,71 \\
\hline 18 & 26,42 & 25,4 \\
\hline 19 & 20,83 & 20,83 \\
\hline 20 & 25,71 & 23,69 \\
\hline 21 & 26.61 & 25,38 \\
\hline 22 & 22,39 & 22,39 \\
\hline 23 & 11,39 & 11,39 \\
\hline 24 & 38,72 & 38,46 \\
\hline 25 & 35,62 & 33,76 \\
\hline 26 & 29,59 & 29,59 \\
\hline 27 & 16,33 & 14,57 \\
\hline 28 & 21,24 & 21,24 \\
\hline 29 & 16,08 & 15,95 \\
\hline 30 & 17,39 & 15,65 \\
\hline
\end{tabular}

Berdasarkan Tabel 2, didapatkan hasil bahwa 24 dari 30 total jarak yang didapatkan menggunakan Simulated Annealing lebih pendek dibandingkan dengan total jarak yang dilalui oleh perusahaan PD Bumi Jaya Indah. Selanjutnya 6 dari 30 total jarak yang didapatkan menggunakan Simulated Annealing sama dengan total jarak yang dilalui oleh Perusahaan PD Bumi Jaya Indah.

\subsection{Pembahasan}

Penelitian ini bertujuan untuk membangun sebuah sistem pencarian rute terpendek pengantaran barang pada PD Bumi Jaya Indah menggunakan metode Simulated Annealing. Adapun yang mendasari penelitian ini adalah masalah pengantaran barang yang dilakukan PD Bumi Jaya Indah yang belum optimal sehingga mempengaruhi jarak, biaya dan waktu pengantaran barang tersebut. Pengantaran barang selama ini dilakukan dengan memperkirakan rute pengantaran barang yang dilakukan oleh kurir PD Bumi Jaya Indah. hal ini menyebabkan pengantaran barang yang tidak optimal sehingga berpengaruh pada jarak, biaya dan waktu yang dikeluarkan oleh PD Bumi Jaya Indah.

Hasil penelitian ini adalah rute terpendek pengantaran barang menggunakan metode Simulated Annealing. Pada sistem ini, kurir perusahaan akan menginput lokasi-lokasi supermarket dan minimarket yang menjadi tujuan pengantaran barang. kemudian Metode Simulated Annealing akan menghitung setiap jarak dari berbagai lokasi yang dimasukkan. setelah penghitungan selesai dilakukan, akan ditampilkan urutan lokasi pengantaran barang beserta rute, jarak, biaya dan waktu yang dibutuhkan dalam pengantaran barang tersebut. tampilan rute yang ditampilkan sesuai dengan google maps dan pengantaran barang dilakukan hanya melewati jalan protokol yang ad di kota Pontianak.

Pengujian dilakukan dengan memasukkan 6 buah lokasi pengantaran barang yaitu PD Bumi Jaya Indah, Ligo Mitra, Anggrek, Garuda Mitra, Mitra Anda Hasanudin dan Ramayana. Metode Simulated Annealing akan menghitung setiap kemungkinan atau kombinasi rute jarak, biaya, dan waktu yang akan dilewati, kemudian akan mengambil nilai terbaik dari seluruh kombinasi rute berdasarkan titik lokasi yang dipilih. Hasil dari pencarian dari 6 buah lokasi yaitu PD Bumi Jaya Indah, Ligo Mitra, Ramayana, Anggrek, dan Garuda Mitra menggunakan metode Simulated Annealing yaitu jarak 22,75 Km, biaya Rp 11287,50 dan 34,125 menit dengan melewati rute (PD Bumi Jaya indah - Ligo Mitra - Ramayana - Anggrek - Garuda Mitra - Mitra Anda Hasanudin - PD Bumi Jaya Indah). 


\section{KESIMPULAN DAN SARAN}

\subsection{Kesimpulan}

Berdasarkan penelitian yang telah dilakukan, dapat disimpulkan sebagai berikut :

1. Metode Simulated Annealing akan menghitung setiap kemungkinan atau kombinasi rute, jarak, biaya, dan waktu yang akan dilewati, kemudian akan mengambil nilai terbaik dari seluruh kombinasi rute, jarak, biaya dan waktu berdasarkan titik lokasi yang dipilih.

2. Hasil pencarian jarak dan rute terpendek yang dilakukan pada 6 buah titik lokasi yaitu PD Bumi Jaya Indah, Ligo Mitra, Mitra Anda Hasanudin, Ramayana, Anggrek dan Garuda Mitra mendapatkan hasil jarak terpendek yaitu dengan jarak $22,75 \mathrm{Km}$, biaya sebesar $\mathrm{Rp} 11287,50$ dan waktu 34,125 menit dengan melewati rute (PD Bumi Jaya indah - Ligo Mitra - Ramayana - Anggrek - Garuda Mitra - Mitra Anda Hasanudin - PD Bumi Jaya Indah).

\subsection{Saran} yaitu:

Adapun saran penelitian selanjutannya,

1. Dapat membuat penelitian ini berbasis android.

2. Dapat menggunakan metode optimasi lainnya dalam pencarian rute terpendek seperti metode greedy, djikstra, ant colony optimization dan lain sebagainya.

\section{Daftar Pustaka}

[1] Rizal J. 2007. Optimasi pada Traveling Salesman Problem (TSP) dengan Pendekatan Simulasi Annealing. Jurnal Gradien Universitas Bengkulu.

[2] Basuki, dkk. Modeling dan Simulasi. Jakarta Selatan. IPTAQ Mulia Media. 2004.

[3] Mahmudy, W, F. Improved Simulated Annealing for Optimization of Vehicle Routing Problem with Time Windows (VRPTW), KURSOR Journal, Vol. 7, No.3, October 2014 ISSN 0216 - 0544.

[4] Samana E., Prihandono B., \& Noviani E. 2015." Aplikasi Simulated Annealing Untuk Menyelesaikan Travelling Salesman
Problem”. Fakultas Matematika dan Ilmu Pengetahuan Alam Universitas Tanjungpura. Pontianak. Buletin Ilmiah Mat. Stat. dan Terapannya (Bimaster) Volume 03, No. 1 (2015), hal 25 - 32.

[5] Juniarto, S, D. 2013. Optimasi Distribusi Barang Berdasarkan Rute Dan Daya Tampung Menggunakan Metode Simulated Annealing. Jurusan Teknik Informatika. Institut Teknik Sepuluh Maret. Surabaya.

[6] Rosa WR., Suhartono., \& Wibawa HA. 2012. Penentuan Jalur Terpendek Pada Pelayanan Agen Travel Khusus Pengantaran Wilayah Semarang Berbasis SIG dengan Algoritma Branch dan Bound. Universitas Diponegoro. Semarang. Jurnal Masyarakat Informatika Volume 4, No. 7 ISSN 2086 - 4930.

[7] Suyanto. 2010. Algoritma Optimasi Deterministik atau Probabilitik. Yogyakarta: Edisi ke-1. Penerbit Graha Ilmu.

[8] Hillier dkk. 2008. Introduction To Operation Research. Jakarta: Penerbit ANDI.

[9] Chibante R, Araujo A, and Carvalho A. 2010. Simulated Annealing Theory with Applications. Croatia: Sciyo. 